\title{
Japan's moves support CoCom
}

- Reagan and Nakasone agree on Toshiba - Stealthy subs issue submerges

\section{- Communist countries remain sceptical} Tokyo

How much substance is there to the allegation that the illegal export of milling machines to the Soviet Union by Toshiba Machine Co. has resulted in a serious breach in the West's security? As the case unfolds it appears that the Toshiba affair has more to do with the internal politics of the United States and the desire of Prime Minister Yasuhiro Nakasone to strengthen US-Japan military links than to the silencing of Soviet submarines.

Nakasone arrived in the United States this week secure in the knowledge that his actions on at least one trade issue have been warmly welcomed by the administration of US President Ronald Reagan. It is less than five months since Toshiba Machine's illegal export of multi-axis milling machines to the Soviet Union was disclosed during Nakasone's last visit to Washington. But already Japan's laws have been rewritten to clamp down on high-tech exports to communist countries.

Earlier this month, the upper house of the Diet passed a revision of the Foreign Exchange and Foreign Trade Control Law which strengthens fines and sanctions against companies violating the rules of CoCom the (Coordinating Committee on Multilateral Export Controls). The Ministry of International Trade and Industry (MITI) will more than double the number of officials monitoring exports to communist countries, and are implementing strict self-control measures.

US Secretary of Defense Caspar Weinberger praised Japan's quick efforts to strengthen CoCom-related laws when MITI minister Hajime Tamura visited Washington on 10 September. And Weinberger said that it would have taken 15 years to enact such legislation in the United States. Therein may lie the key to the whole Toshiba affair.

Earlier this year the US National Research Council argued in a report that the Pentagon is hurting US industry through limiting exports to the Soviet bloc (Nature 325, 291; 1987). And the US Congress has incorporated provisions into its omnibus trade bill to reduce the number of items on the "controlled list" and to loosen export regulations. The Pentagon, on the other hand, is pressing for stricter controls.

The US Defense Department knew about Toshiba Machine's illegal export of milling machines to the Soviet Union long before the story broke in the Japanese and US press in late April and some US obser- vers suspect that the Pentagon may have used the Toshiba incident to counter the moves by Congress. Although stressing that the Toshiba sale was illegal, William A. Root, former head of the US CoCom delegation, said the issue had been "dramatized" by the various parties, and that the timing looks "particularly motivated".

Central to the Pentagon's condemnation of Toshiba Machine $\mathrm{Co}$. is the claim that the milling machines have been used to make propellers that produce less cavitation noise and, as a result, Soviet submarines are now harder to detect. But the crucial factor determining cavitation noise is the design of the propeller, not the machines that mill it. And there are many other sources of noise in submarines apart from the propeller. Furthermore, quieter Soviet submarines began to appear before the Toshiba machines were operational (Nature 328, 283; 1987).

According to Root, illegal exports of

Soviets stress CoCom
complications
London

Soviet political commentators, who to say the least, are naturally not enamoured of CoCom, are presenting the Toshiba affair as an attempt by the United States to keep west Europeans out of Eastern-bloc markets, both for political and commercial motives. This line of argument has been particularly aimed at the Scandinavian audience, in view of the alleged involvement of the Norwegian firm Kongsberg Vapenfabrikk. Moscow radio's Swedish and Finnish services have also linked the Toshiba story with Sweden's adoption last year of new export controls which are basically identical with those of CoCom (unlike Norway, neutral Sweden is not a CoCom member), although the new law was adopted many months before the Toshiba affair became public. They were, in fact, inspired by an attempt to smuggle computer hardware and software to the Soviet Union via Sweden, in 1983 (see Nature 303,$635 ; 1983$ ).

The Soviets present the new law as evidence of US pressure on Sweden, and cite a report in the Stockholm daily Dagens Nyheter last month that, at the request of the United States, Swedish customs are now investigating two Swedish companies alleged to have secretly supplied a socialist country with US-made microprocessors.

Vera Rich high technology to communist countries from western Europe and the United States are common. For example, the Soviets broke off previous negotiations with Toshiba in 1981, claiming they could get the same items at lower prices elsewhere. And, in a recently released report on the Toshiba incident prepared by US and Japanese law firms at the request of Toshiba Corporation (the parent company of Toshiba Machine Co.), it was revealed that Toshiba Machine employees saw a multi-axis propeller milling machine made by the French firm Forest Line when they were installing their machines at a Soviet shipyard on the Baltic in 1983. Forest Line deny breaking CoCom regulations restricting export of machines with more than three axes, but multi-axis machines can be made by running simpler devices in tandem, using control systems of the kind made by Kongsberg-Vapenfabrikk of Norway.

The Toshiba story surfaced in the press at a time that Japan and the United States were finalizing an accord to Japan's participation in the research phase of the US Strategic Defense Initiative (SDI). And the hullabullo over Toshiba has allowed the Nakasone administration to rush the toughened export control law through the Diet, thereby preparing the stage for the participation of Japanese companies in SDI (according to leaks to Japanese newspapers, the secret SDI accord calls for strict observance of CoCom regulations by both countries). Nakasone has also called for US-Japan cooperation in antisubmarine warfare research in the wake of the Toshiba incident and consultations have already been held.

The Nakasone and Reagan administrations, however, are not alone in taking advantage of the Toshiba incident. US congressmen have gone on a rampage of "Japan bashing" that has included pulverization of Toshiba cassette recorders in public. And Congress has introduced clauses in its trade bill to ban imports of Toshiba products to the United States. But the Reagan administration has vowed to fight these and other protectionist clauses by, if necessary, invoking a presidential veto. US industry has recently rallied to the administration.

The most significant consequence of the Toshiba affair for Japan, however, may be a deterioration in relations with communist countries. China is complaining that Japanese companies have cancelled $\$ 1,800$ million in contracts since the Toshiba case. MITI is considering slackening export regulations for China, but for the other 13 communist countries on the ministry's list strict controls will be maintained.

David Swinbanks 